\title{
Når hjernen svikter
}

Engelsk oversettelse av hele artikkelen på www.tidsskriftet.no

I disse dager er det 105 år siden Alois Alzheimer (1864-1915) for første gang presenterte sykehistorien til den da nylig avdøde Auguste D (1850-1906). Kvinnen var blitt syk i 50-årsalderen, og i flere tiår etter Alzheimers beskrivelse ble tilstanden, «presenil demens», betraktet som en sjelden sykdom som kun forekom hos yngre. I løpet av 1960- og 70-årene ble det imidlertid klarlagt at amyloide avleiringer også forekommer i hjernen hos eldre med demens. Denne innsikten var viktig for å endre synet på tilstanden. Til da hadde man oppfattet det at eldre ble «rørete» som et uunngåelig naturfenomen. Denne forestillingen er ennå rotfestet, blant annet i det feilaktige uttrykket «senil» som betegnelse på den demenssyke. Alle som har opplevd utvikling av demens på nært hold, vil imidlertid være enig $i$ at dette er noe annet enn et normalt aldersfenomen; nemlig en progredierende og dødelig hjernesykdom.

Myten om demens som et uunngåelig aldersfenomen uten nytte av intervensjon gjenspeiles dessverre $\mathrm{i}$ hvordan man i helsevesenet har valgt å organisere utredningen av sykdommen. Andre sykdommer av en slik alvorlighetsgrad blir utredet i spesialisthelsetjenesten. Når det gjelder demens, er Norge et av få land der man har valgt å legge hovedansvaret for utredning og diagnostikk til primærhelsetjenesten. Der må oppgaven slåss med fastlegenes alle andre viktige gjøremål. Regjeringens Demensplan 2015 har riktignok bidratt til at nærmere halvparten av norske kommuner nå har opprettet demensteam eller demenskoordinatorer. Målsettingen for demensteamenes sammensetning er imidlertid beskjeden: Det «bør være lege tilknyttet demensteamet», slår Helsedirektoratet fast - det likner mer et fromt ønske enn et minimumskrav (1). Dette til tross for at demensteamets primære arbeidsoppgaver skal være «demensutredning og oppfølging» (1). Heller ikke i spesialisthelsetjenesten er utredningstilbudet ved demens enhetlig, og flere steder oppleves det som nesten fraværende (2). Da er det ikke rart om mange travle fastleger føler seg alene med en utredningsoppgave som er økende i både kompleksitet og omfang.

En fersk internasjonal metaanalyse og en ny oversiktsartikkel dokumenterer begge lav diagnostisk presisjon av demens i primærhelsetjenesten $(3,4)$. I Norge blir kun halvparten av alle med demens diagnostisert, og i en undersøkelse hadde en tredel av demente nylig innlagt i sykehjem ikke fått stilt demensdiagnosen (5). Det er altså en betydelig underdiagnostisering av demens slik utredningen nå er organisert. Spiller dette noen rolle for den enkelte demenspasient? De siste 20 årene har det skjedd store fremskritt både i patofysiologiske innsikter og i bruk av bildediagnostikk og biomarkører i klinisk diagnostikk. Dessverre er fremdeles den medikamentelle behandlingen lite effektiv, og flere nye medikamenter som virket lovende, har nylig gitt skuffende resultater i fase 3-studier (6).

Likevel er tidlig og korrekt diagnostikk av demenssykdom viktig. De patofysiologiske prosesser ved Alzheimers demens begynner flere år før sykdommen blir klinisk evident, og tidlig behandlingsstart er viktig. Mange vanlige medikamenter kan gi atypiske reaksjoner og ha en mer ugunstig bivirkningsprofil hos demente enn hos andre. Hos en del pasienter er det dessuten potensielt reversible årsaker til den kognitive svikten. For disse er korrekt og tidlig diagnostikk spesielt viktig. Det er også vist at hos hjemmeboende med demens kan institusjonalisering utsettes med i gjennomsnitt 18 måneder ved å gi opplæring, rådgiving og støtte til pårørende (7). Tidlig diagnose er derfor avgjørende. Dette øker også muligheten for at pasienten selv kan være med på viktige avgjørelser, som for eksempel utarbeiding av testament og valg av senere omsorgssted.

Det er beregnet at antallet mennesker med demens i Norge vil bli mer enn fordoblet i løpet av de neste 40 årene (8). Mye er skrevet om den enorme økningen i behov for omsorgstjenester dette vil gi. Betydelig mindre er skrevet om det økende behovet for tidlig og korrekt diagnostikk. Utredning av demens kan være vanskelig og stiller stadig større krav til faglig oppdatert kunnskap og bruk av spesialundersøkelser. Konsekvensene av forsinket eller feilaktig diagnostikk kan være store. Gitt den nåværende kapasiteten vil ikke alle pasienter med symptomer på demens kunne utredes innenfor de relevante spesialitetene geriatri, psykiatri og nevrologi. Det nye kompetanseområdet $i$ alders- og sykehjemsmedisin vil måtte vektlegge demenskunnskap, men er i hovedsak rettet mot pasienter innlagt i sykehjem. Utredning og diagnostikk av demens må skje før dette stadiet av sykdommen. Mye tyder på at tidlig og multidisiplinær tilnærming, med bidrag fra både geriatri, psykiatri og nevrologi, er det optimale (9). Da må vi i mye større grad enn i dag sentralisere demensutredningen til regionalt eller flerkommunalt nivå, med spesialiserte utredningsenheter som nasjonal gullstandard. Demens vil bli en av helsevesenets største utfordringer i årene som kommer. Da trengs det demensteam i alle kommuner for tidlig oppdagelse og senere oppfølging, men også klarere og mer ambisiøse standarder for spesialisert og tidlig utredning, slik det er for andre progredierende og dødelige sykdommer.

\section{Are Brean}

are.brean@legeforeningen.no

Are Brean (f. 1965) er ph.d. og spesialist i nevrologi. Han er medisinsk redaktør i Tidsskrift for Den norske legeforening og leder i Norsk nevrologisk forening.

Ingen oppgitte interessekonflikter.

\section{Litteratur}

1. Etablering og drift av demensteam. Demensutredning i primærhelsetjenesten. Oslo: Helsedirektoratet/Nasjonalt kompetansesenter for aldring og helse, 2011.

2. Eek A, Nygård AM. Lysning i sikte? Tilbud til personer med demens i norske kommuner. Tønsberg: Aldring og helse, 2006.

3. Dungen P. Marwijk HW. Horst HE et al. The accuracy of family physicians' dementia diagnoses at different stages of dementia: a systematic review. Int J Geriatr Psychiatry 2011; e-publisert 30.5.

4. Mitchell AJ, Meader N. Pentzek M. Clinical recognition of dementia and cognitive impairment in primary care: a meta-analysis of physician accuracy. Acta Psychiatr Scand 2011; 124: 165-83.

5. Nygaard HA, Ruths S. Missing the diagnosis: senile dementia in patients admitted to nursing homes. Scand J Prim Health Care 2003; 21: 148-52.

6. Barnes D, Yaffe K. The projected effect of risk factor reduction on Alzheimer's disease prevalence. Lancet Neurol 2011; 10: 819-28.

7. Mittelman MS, Haley WE, Clay OJ et al. Improving caregiver well-being delays nursing home placement of patients with Alzheimer disease. Neurology 2006; 67: $1592-9$.

8. Hjort PF, Waaler HT. Demens frem mot 2050. Tidsskr Nor Legeforen 2010; 130 $1356-8$.

9. Nilsson C. Multidisciplinärt fokus på kognitiv svikt och demens. Läkartidningen 2009; 20: 1367-8. 